\title{
Has Land Sharing Achieved Its Objective To Maintain The Poor In Inner City?
}

\author{
Querida Khotcharee \\ Institute of Metropolitan Development, Navamindradhiraj University, Bangkok, \\ THAILAND \\ E-mail address: querida@nmu.ac.th/qleera@gmail.com
}

\begin{abstract}
This research aims to explain and analyze to what extent social and physical capital influence the decision of original households in Land Sharing project to remain living on the same site, as it is one of the main objectives of land Sharing concept. Qualitative explanatory case study research design was conducted in four case studies in inner Bangkok through multi-sources data. This study extracted participants' opinion to remain on-site using the semi-structured in-depth interview. Besides, practitioners and academic scholars were interviewed; secondary data were also used to triangulate the data sources. Furthermore, an open site observation was adopted to collect data on physical attributes of case studies.

The study reveals that Land Sharing scheme can maintain the urban poor in the inner city to some extent. Not all original households stayed in the same project after more than 20 years of implementation. Reasons that influenced them to stay to achieve their livelihood goal were not only physical capital and social capital, but they also combined all livelihood assets. To what extent each asset influenced the decision to stay, relations among each asset, discussion, and suggestion for policymaker and practitioner were also discussed in this study.
\end{abstract}

Keywords: Land Sharing, On-site Slum Upgrading, Livelihood Assets, Urban Poor, Urban Development

\section{Introduction}

Land conflict in Thailand issues in the 1970s to 1980 s derived from the land demand for urban development projects in both the public and private sector due to the rapid economic development in that period. Also, the poor, from the rural area came to Bangkok for better job opportunities compared to their hometown, also 
seeking for vacant land to build their shelters. As a result, the urban population in Thailand rose from 29\% to 44\% between 1999 and 2014 (Bhatkal \& Luccy, 2015). Most of the landowners of those vacant lands are public authorities such as State Railway of Thailand, Department of Treasury, Thailand Transport Portal, Department of Highway, the King's Property Bureau and the Crown Property Bureau. In some cases, the poor squatted on the abandoned land of private landowners that was not yet developed. The high competition in urban land use pushes the urban poor to live under a threat of eviction in unpleasant settlements because it is hard to obtain security of tenure of land ownership (Porio \& Crisal, 2004).

Land Sharing is one variation of on-site slum upgrading that can address land conflict issues. It was first introduced and has been implemented in Thailand since the 1980s (Islam \& Yap, 1989). This model divides squatted land into two parts. One part for the poor to build their new houses with full security of tenure, and another parcel for the landowner to develop the land at highest and best use, then use benefit gains from the land to cross-subsidize housing for the poor. This land management tool seeks for agreement between landowner and squatters (Islam \& Yap, 1989; Rabé, 2005; Rabé, 2010; Talocci \& Boano, 2017). Moreover, the unique characteristics of Land Sharing scheme include remaining of the urban poor in the inner city and share increased value of the land from commercial development to finance low-income housing.

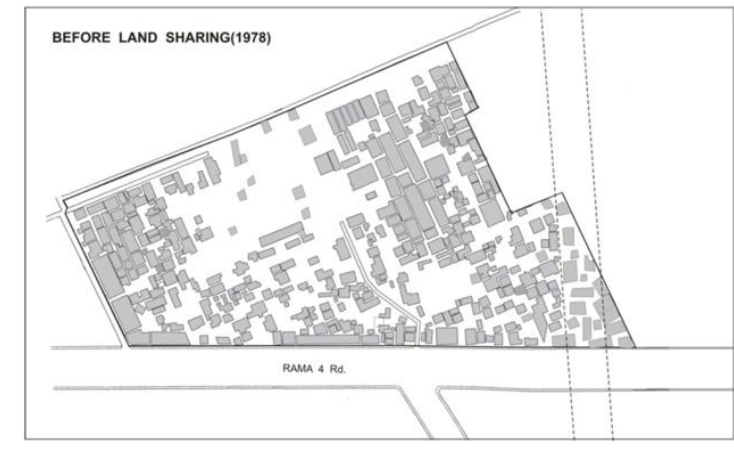

(a) Before implemented Land Sharing

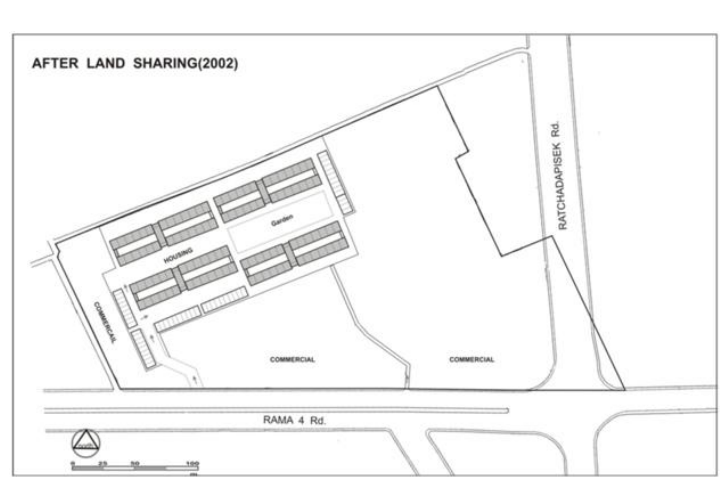

(b) After implemented Land Sharing

Figure 1: Housing Arrangement Transformation in Land Sharing Process Source: Rabé \& Leeruttanawisut (2003), pp.9

The dynamic and complex situation in the urban area is an external environment that makes the urban poor in risk and uncertainty of being an eviction or relocate, their assets and the poor themselves are vulnerable from such situations (Rakodi, 2002). 
They collected their assets both tangible, such as their land, house or jewelry, and intangible, such as their skills, health, labor, or knowledge to maintain their "livelihoods - capacities, assets, and activities that required for a mean of living. The livelihood of the poor is sustainable when it can cope with and recover from stress and shocks and maintain its capabilities and assets both now and in the future" (Carloni \& Crowley, 2005).

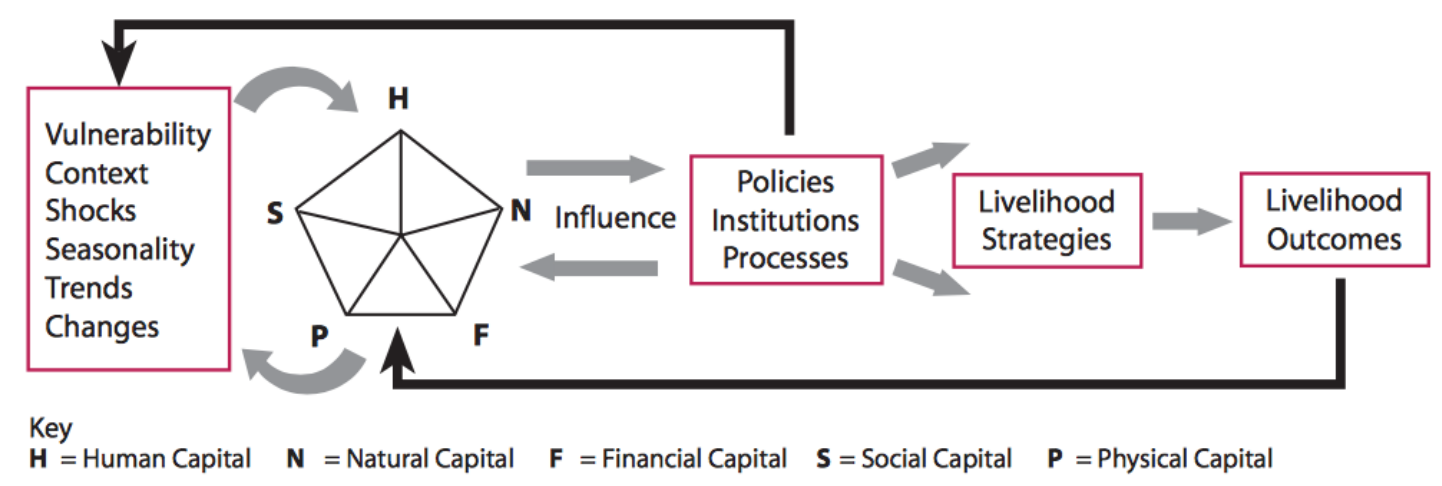

Figure 2: Sustainable Livelihood Framework

Source: Carloni \& Crowley, 2005, pp.2

According to Rakodi (2002), policy design and implementation often consider five livelihood assets because they are important to the urban poor to counter with the shock and uncertainty of living in the city. However, two assets were selected to frame this research: social capital and physical capital. Social capital was mostly mentioned in slum upgrading and Land sharing studies in various aspects. Also, physical capital is directly involved with Land Sharing because it is focused on physical conditions of the poor's housing and basic service and infrastructure in the slums (van Horen, 2000; O'Hare, 2001; Satterthwaite, 2010; Meredith \& MacDonald, 2017). However, natural capital was excluded from the study because natural resources were far from the urban context since it includes land, water, and other environmental resources that are most important for a rural area

On-site slum upgrading, especially Land Sharing, is the policy context that helps the poor to be able to stay in the city because it gives opportunities to have their house near their workplace, also, low-income labor is an essential factor for the informal economy of the city (O'Hare, 2001; UN-Habitat, 2003; Dupont, 2008; Satterthwaite, 2010). However, it is hard for the poor to avoid an effect of economic growth and urban policy. The question is even the objective of maintaining the poor in the same 
site and help them retain their livelihood assets, but has the policy success? After Land Sharing has been implemented for more than 20 years, there is a need to investigate if the policy succeeds or not. Has Land Sharing maintained the poor there on-site? For those who are still there, does the presence of livelihood assets a reason that slum dwellers stay on site? In general, assets that mostly mentioned in slums development are social and physical capital. Are they determinants of Land Sharing to maintain the urban poor in the inner city? Moreover, from the pre-literature review, there were no researches conducted to evaluate the success of the Land Sharing projects in the recent year. So, this study could also fill this research gap.

The objective of this research is "to explain and analyze to what extent social and physical capital influence the decision of original households in Land Sharing project to remain living on the same site?" From the objective, the main research question of this research is "What are the reasons that influence the decision of original households in Land Sharing project to remain living on the same site?"

\section{Methods}

This research adopted the co-variance case study using multiple cases to get both breadth and depth information. Case study strategy also helped to gain the depth of the findings (van Thiel, 2014) in this study. Also, the co-variance approach was used to observe the co-variation between causal factors - independent variables (social capital and physical capital) and causal effect - dependent variables (the poor stay on-site in long-term period) (Blatter \& Blume, 2008). Also, this research collected the primary qualitative data using the semi-structured in-depth interview.

Researcher conducted an in-depth interview with original Land Sharing households, which include households that have at least one member since Land Sharing agreement has been signed still living on-site of the project and close relatives such as children, grandchildren or siblings of the original households' members. Also, community leaders and community committee along with housing development practitioner and scholar were interviewed. However, community members that have been living in the Land Sharing project in the long term are also main respondents. Their opinions were extracted through the semi-structured interview of why they are still staying on-site until this point of time? In sum, there were 20 respondents in this research as shown in table 1 below. 
Table 1: Characteristics of research sampling

\begin{tabular}{|c|c|c|c|c|}
\hline Project & Name & Age & Gender & Specialization \\
\hline \multirow{4}{*}{$\begin{array}{l}\text { Moo Baan } \\
\text { Pattana } 70 \text { Rai }\end{array}$} & Tongkam Saekow & $60+$ & Male & Community leader \\
\hline & Nuttanan Saelee & $40-59$ & Female & Community Secretary \\
\hline & Sumitra Boonsiri & $60+$ & Female & Retailer (drugstore) \\
\hline & Jarassri Sritorn & $40-59$ & Female & Rental house \\
\hline \multirow{8}{*}{ Thep Pratan } & Lek & $40-59$ & Male & Food seller/Community leader \\
\hline & Somrak Ponwittayanon & $40-59$ & Female & Food seller/community committee \\
\hline & Samean Duangchan & $60+$ & Female & Housewife \\
\hline & Lalana & $25-39$ & Female & Private company \\
\hline & Prasong Sudyodbanpot & $40-59$ & Male & Entrepreneur (electronic parts) \\
\hline & Building 1 , house 1 & $25-39$ & Male & Private company \\
\hline & Building 1 , house 1 & $25-39$ & Female & Private company \\
\hline & Building 1, house 2 & $60+$ & Female & Housewife \\
\hline \multirow[t]{2}{*}{ Soi Sengki } & Charnchai Kittiwat & $40-59$ & Male & Food seller/community secretary \\
\hline & Mrs.Taew & $60+$ & Female & Housewife \\
\hline \multirow[t]{3}{*}{ Wat Lad Bua Kaw } & Pranee Panbua & $60+$ & Female & Community Leader \\
\hline & Aurapin Sridachart & $40-59$ & Female & Community secretary \\
\hline & Nuanla-au Ngernliangchip & $60+$ & Female & Housewife \\
\hline Project Manager & Pichitsak Meemak & $25-39$ & Male & CPB officer, Thep Pratan \\
\hline \multirow[t]{2}{*}{ Academic } & $\begin{array}{l}\text { Asst. Prof. Koen de } \\
\text { Wanseler, Ph.D. }\end{array}$ & $60+$ & Male & Human Settlements \\
\hline & $\begin{array}{l}\text { Asst. Prof. Kundoldibya } \\
\text { Panitchpakdi, Ph.D. }\end{array}$ & $60+$ & Female & $\begin{array}{l}\text { Housing, and real estate } \\
\text { development }\end{array}$ \\
\hline
\end{tabular}

Source: Author, 2017

Case studies were chosen based on the population size of the projects from the literature review. Social capital consisted of community bonds and networks, also trust within community members (Loury, 1976; Bourdieu, 1985; and Coleman, 1988; Rakodi, C., 2000), so, the smaller size of the community that developed by Land Sharing may or may not have stronger networks than the larger community. 
Table 2: Overview of Original Land Sharing Projects in Bangkok

\begin{tabular}{|l|l|r|r|}
\hline \multicolumn{1}{|c|}{ Projects } & \multicolumn{1}{c|}{ Landowners } & Total Area (ha.) & $\begin{array}{c}\text { Households } \\
\text { number }\end{array}$ \\
\hline 1) Wat Lad Bua Kaw & Private landowners & 1.6 & 63 \\
\hline 2) Soi Sengki & The King's Property Bureau & 1.1 & 143 \\
\hline 3) Sam Yod & The Crown Property Bureau & 0.95 & 182 \\
\hline 4) Manangkasila & Treasury Department & 1.6 & 197 \\
\hline 5) Klong Pai Singto & The Crown Property Bureau & $\mathrm{n} / \mathrm{a}$ & 380 \\
\hline 6) Plab Pla & The Crown Property Bureau & 69 & 436 \\
\hline 7) Moo Baan Pattana 70 Rai & Port Authority of Thailand & 6.8 & 700 \\
\hline 8) Thep Pratan & The Crown Property Bureau & & 914 \\
\hline
\end{tabular}

Source: Adapt from Rabé, E. P. (2010); Panitchpakdi et al. (2014)

Table 2 shows eight original Land Sharing Projects in Bangkok, which differs in plot size and household size. Two smallest projects - Wat Lad Bua Kaw and Soi Sengki - and two biggest projects - Moo Baan Pattana 70 Rai and Thep Pratan were chosen as case studies in this research.

Interviews were transcribed after data collection, researcher coded interview transcripts and analyzed the data using ATLAS.ti software to facilitate different analysis, including content analysis and data interpretation. Two steps of analysis were conducted. First, interview transcriptions were coded into 30 codes and grouped into ten code groups regarding variables of four livelihood assets from the literature review (see diagram 1).

Second, relationships between each factor were analyzed to explain how they influenced the decision of the original Land Sharing residents to stay at the same site in long-term. The query tool technique was adopted to analyze difference and similarity of factors that influenced the decision to remain on-site of original residents in large and small Land Sharing projects. 


\section{Diagram 1: Codes, code groups, and code descriptions}

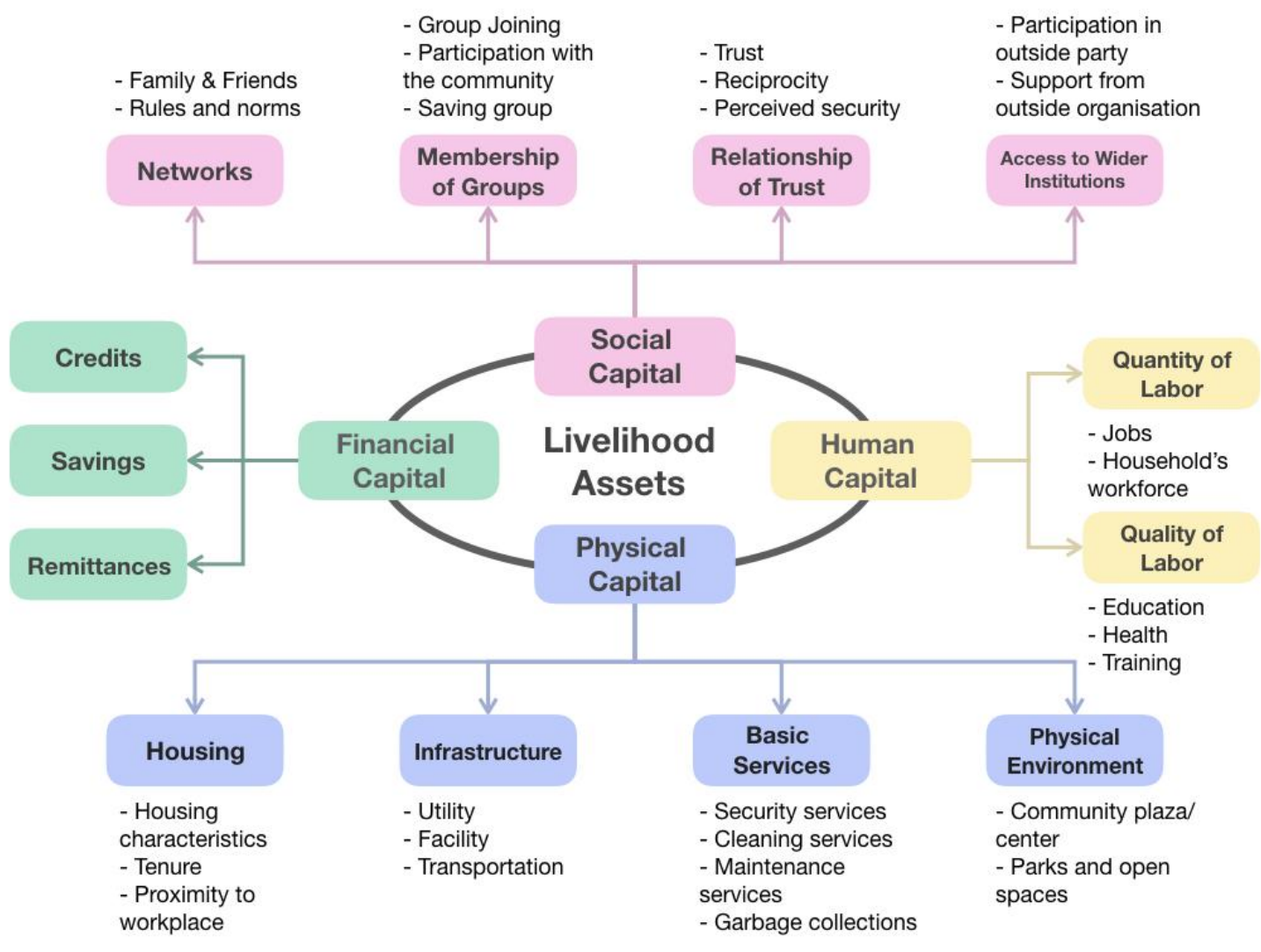

Source: Author, 2017

\section{Results}

Original Land Sharing residents decided to stay on site as a strategy to achieve their livelihood outcome, however, not all of them decided to stay. The project that has the largest ratio of original residents is Wat Lad Bua Kaw, while smallest is Moo Baan Pattana 70 Rai (see table 3 ) because there was a replacement of the original residents with sublet tenants or new residents. It is supported by Vilar and Cartes's (2017) findings that the physical improvement may have resulted in speculation development and the area would be gentrified. The research result brought a question on evaluating the success of the Land Sharing project by maintaining the income level for the poor that could benefit the urban poor in the whole society, rather than limited to the urban poor that signed to Land Sharing contract. 
Table 3: Estimation of remaining households on-site

\begin{tabular}{|l|c|c|c|}
\hline \multicolumn{1}{|c|}{ Project } & $\begin{array}{c}\text { Current } \\
\text { household }\end{array}$ & $\begin{array}{c}\text { Remaining original } \\
\text { household estimation } \\
\text { (\%) }\end{array}$ & $\begin{array}{c}\text { Remaining original } \\
\text { household estimation } \\
\text { (n) }\end{array}$ \\
\hline Moo Baan Pattana 70 Rai & 1,120 & $25 \%-50 \%$ & $280-560$ \\
\hline Thep Pratan & 846 & $80 \%$ & 677 \\
\hline Soi Sengki & 126 & $30 \%-50 \%$ & $38-63$ \\
\hline Wat Lad Bua Kaw & 64 & $92 \%$ & 59 \\
\hline
\end{tabular}

Source: The municipality of Klong Toei, 2016; The Crown Property Bureau, 2017; The municipality of Bangkolaem, 2017

\section{Social and Physical Capital as Dominant Factors}

Research findings revealed that social and physical capital are dominant factors in influencing the decision to stay at the same site of original Land Sharing residents as explained:

\section{Social capital}

Social capital includes four aspects: networks, membership of groups, the relationship of trusts, and access to wider institutions. The most important issue of social capital is "networks", which includes networks of family members, relatives, or friends in the community that bonded residents together. In many cases, original residents invited relatives to come to stay in the same project. Another example was that close relatives sent their children to live with the original households for education or work in the surrounding area of the case study. In this case, they tend to stay longer on the project because their family members and close friends also remain within the same community. All of the respondents in this research have been staying in the area for a long time, even before the Land Sharing scheme was applied. The findings confirmed Putnam (1995) and DeFilippis (2001) statement that social capital is essential for the urban poor because networks between them are the assets that already exist in the community. The network mentioned above is "bonding social capital" that members of the network tried to maintain the membership through cooperation and trusts (Szreter, 2003).

The stronger networks, the higher the level of trusts and reciprocity among 
residents in the group. Interestingly, residents in all case studies viewed newcomers in the project (mostly tenants) as an outsider. They did not trust renters as much as they believe their long friends or relatives, even those renters are their neighbor next door. On the other hand, trust level was extremely high in many cases as they were able to leave their house keys or asked their neighbors to keep parcels from postman for them. To confirm, residents mentioned during the interview that they still stay in the same house because they do not want to start building a new relationship again, especially when they do not know anyone in the new community.

Also, membership of the group is also the critical factor. Working group and the saving group increased chances to earn more income or access to loans. The working group or community enterprise not only offers a sustainable job opportunity for community members, but also strengthen the community bonds, capacity, and responsibility of them from the self-determined and self-managed activities of the residents (UN-Habitat, 2009). Work-related associations found in this study are dockyard labor group, tax sticker labeling group, and vegetable (chili) preparing group. All of these groups found in Moo Baan Pattana 70 Rai project, which located near Bangkok Port, Klong Toei market and Penang market. Households gained social capital through the working process and trusts through the activity of the group as supported by Putnam's (1993) view that social capital realized by the group, and it is easier to gain social capital when residents cooperate a group activity.

Saving group is also a crucial factor. Not only savings and interests but the saving group also provides another benefit to members. In Thep Pratan, there is pocket money for members who gave birth or death, and subsidy for hospital expenses when falling sick. Furthermore, the community committee is another group that also provided an opportunity to earn more income. Community leader received a salary from the local municipality (district) that the community has been registered. Such earnings depend on a population size of the community. The local municipality also provides funds for each community to manage projects and activities for community members. In some occasions, extra support such as gifts, donations (goods or money) will be provided.

Support from the outside organizations was significant in the beginning process of Land Sharing. Without them (see table 5), the project could not be accomplished because residents would not be able to gain access to low-interest rate loan for land, loan guarantee, utility, and facility, and most importantly, the special permission to build housing non-regarding building Act. Many of houses in Land Sharing projects did 
not respect the law, for example, minimum plot-size, set-back, or open space between building. The local authority, landowner, NGOs, or educational institutions can support the community by assisting the residents in the project to form a group and propose for the community development fund (CDF) in national level. After the community has established and they repay all loans, roles of facilitator organizations were less. Residents prefer the support that directly involved or affected them, such as scholarship, food, infant milk, and diapers, or housing maintenance. Training programs were less interested among residents because the programs are not related to their present job, nor cannot generate income. Also, those training often organize during the daytime that most of the residents are working on the project. They will join new activities or group only when they counter with the situation that they cannot achieve alone as (Szreter, 2003) mentioned in bridging social capital.

\section{Physical capital}

Respondents addressed all aspects of physical capital as a reason why they were still staying at the same project in a long time for more than ten years. Housing, infrastructure, basic services, and physical environment were all addressed positively. Surely, all housing and infrastructure were upgraded regarding the main objective of on-site slum upgrading projects (van Horen, 2000; UN-Habitat, 2003; Satterthwaite, 2010; Wekesa, Steyn \& Oteino, 2011; Archer, 2012; Minnery et al., 2013). No exception, respondents in this study also satisfied with the condition of their new housing and infrastructures.

Location of the house is the factor that most influenced residents to remain on the same site. All case studies located in a relatively prime area in inner Bangkok. It is an advantage of implementing Land Sharing that remain the urban poor in the same site, while the developer can develop that parcel in shorter operational time (Rabé, 2010). All participants have good access to main road and mass transportation as shown in Figure 3 and 4 . The location of the project made it easy to travel to important destinations, for example, market (whether to buy or to sell goods and services), school, hospital or park. Respondents spent shorter time and less effort in traveling to work or urban facilities. Besides, the location of the project gave greater job opportunity. It confirmed with O'Sullivan (2012) statement that the location near CBDs or commercial area gave more job opportunity for the urban poor. The projects were surrounded by important CBDs, commercial areas, and offices in Klong Toei and Bangkolaem district in Bangkok. Residents in Moo Baan Pattana 70 Rai directly 
benefited from the short proximity to Bangkok Port. Community committee mentioned that more than 50 percent of residents in the project work at the port. Residents from Thep Pratan, Soi Sengki, and Wat Lad Bua Kaw also mentioned that they intentionally chose the location of workplace nearby their houses because they also have to take care of their family members.

Figure 3: Location and surroundings of Thep Pratan and Moo Baan Pattana 70 Rai

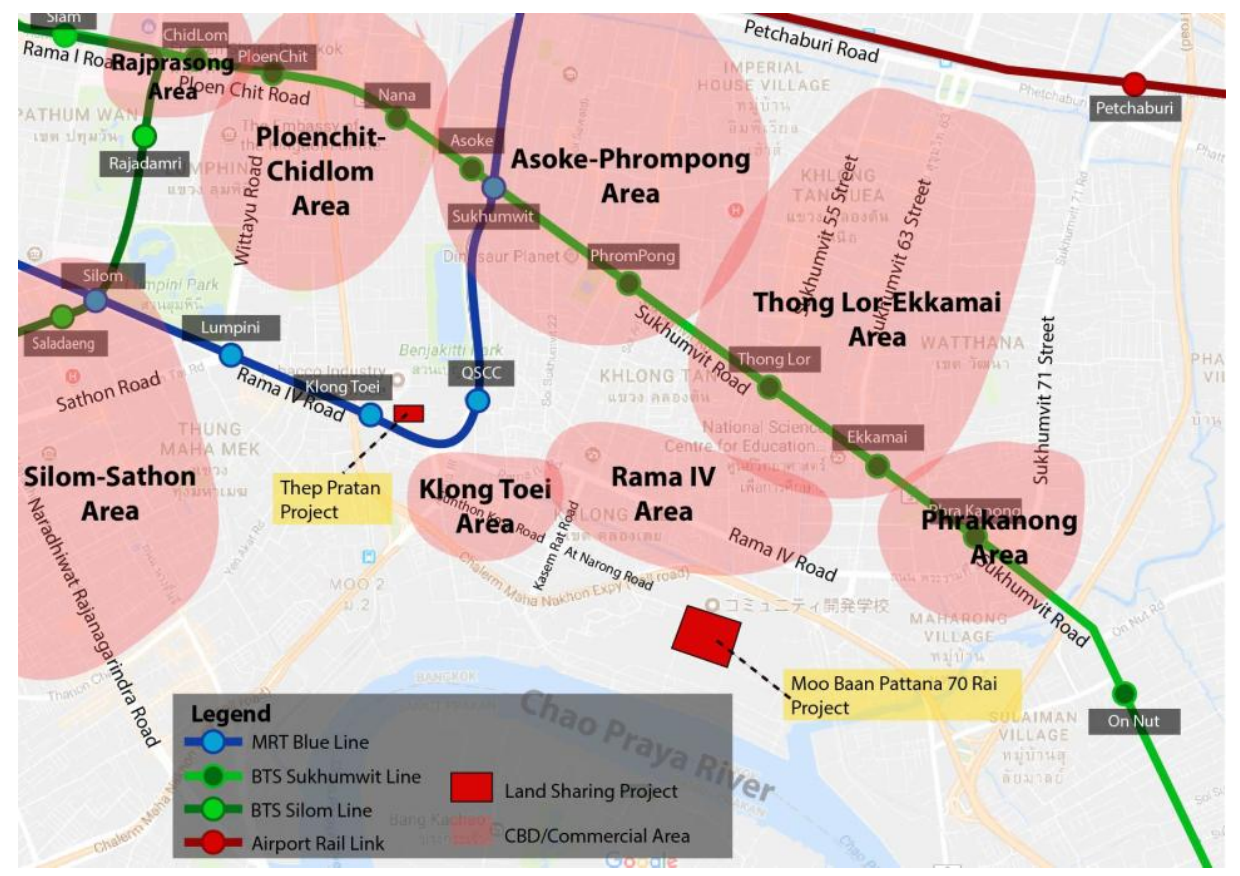

Figure 4: Location and surroundings of Soi Sengki and Wat Lad Bua Kaw 


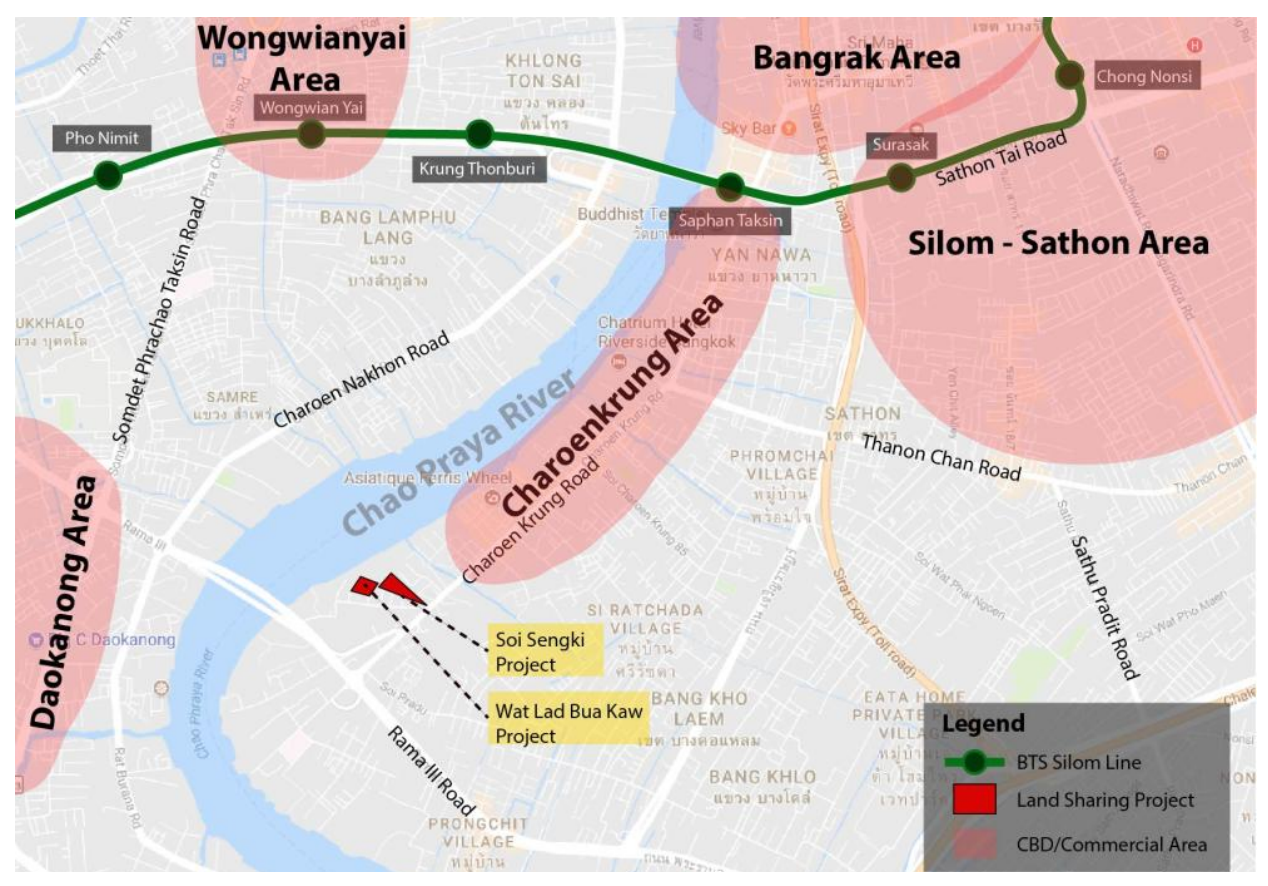

Also, secured tenure influenced original Land Sharing households to stay because it is the guarantee that their family members have a secured home for the rest of their life. In addition, workforces can go to work without any worry as they can leave children with their parents and send money to support them, while the secured house was their place to stay in case they lose jobs. As discussed in social capital, sometimes relatives sent their children to stay with original residents because of the location of the house is located in the prime area with better schools compared to ones nearer to their own home. Furthermore, residents from freehold projects can use the land deed as a guarantee for loans for their business or housing maintenance or renovation.

Table 4: Case Studies Tenure Characteristics

\begin{tabular}{|l|c|c|c|}
\hline \multirow{2}{*}{\multicolumn{1}{|c|}{ Project }} & Before Land Sharing & \multicolumn{2}{c|}{ After Land Sharing } \\
\cline { 2 - 4 } & Tenure form & Tenure form & Lease Duration \\
\hline Moo Baan Pattana 70 Rai & Squatting & Leasehold & 30 years \\
\hline Thep Pratan & Squatting & Leasehold & 30 years \\
\hline Soi Sengki & Leasehold & Freehold & - \\
\hline Wat Lad Bua Kaw & Leasehold & Freehold & - \\
\hline
\end{tabular}

Source: Author, 2017 
Because of the support from project facilitators and characteristics of the landlord, households enjoyed the low land price or low rental rates. This scenario shows another linkage between physical and social capital. It can be implied that cheaper rental rate or low land price increased households' savings to invest or gave the better education for their children. Characteristics of the landlords are more critical for leasehold projects than freehold project. If the organization was known as a good governance organization, it gave more confidence to households that they will not be force evicted from the project.

In conclusion, social capital and physical capital are inseparable. They were closely associated with one another. Not only these two, but households also collected all four capitals to achieve their livelihood goal, in this case, to stay in the same area in the long-term period. 
Table 5: Summary of support from wider institutions in Land Sharing Projects

\begin{tabular}{|c|c|c|c|c|}
\hline \multirow[b]{2}{*}{ Issue } & \multicolumn{4}{|c|}{ Facilitator Organizations } \\
\hline & $\begin{array}{c}\text { Moo Baan } \\
\text { Pattana } 70 \text { Rai }\end{array}$ & Thep Pratan & Soi Sengki & $\begin{array}{c}\text { Wat Lad Bua } \\
\text { Kaw }\end{array}$ \\
\hline Landlord & PAT & CPB & KPB & Private landowner \\
\hline Project size & 70 Rai (11.2 ha) & 15.1 Rai (2.4 ha) & 1,508 Square Wah & 2 Rai \\
\hline $\begin{array}{l}\text { Housing plot / } \\
\text { unit size }\end{array}$ & $\begin{array}{l}15 \text { and } 22 \text { square } \\
\text { Wah }\end{array}$ & 60 square meters & 6 and 12 square Wah & $\begin{array}{l}34-59 \text { square } \\
\text { meters }\end{array}$ \\
\hline Land negotiation & $\begin{array}{l}\text { Klong Toei Slum } \\
\text { Federation } \\
\text { approached NHA }\end{array}$ & $\begin{array}{l}\text { Occupier form } \\
\text { Credit Union } \\
\text { Cooperative }\end{array}$ & $\begin{array}{l}\text { Occupier form Sengki } \\
\text { Housing Cooperative } \\
\text { to negotiate with the } \\
\text { KPB, which was } \\
\text { willing to make } \\
\text { consensus }\end{array}$ & $\begin{array}{l}\text { Army General Arthit } \\
\text { Kamlang-Ek } \\
\text { consulted with son } \\
\text { of the landlord }\end{array}$ \\
\hline $\begin{array}{l}\text { Rights } \\
\text { arrangement }\end{array}$ & $\mathrm{NHA}$ & $\begin{array}{l}\text { NHA, GHB, Ministry } \\
\text { of Finance and } \\
\text { development } \\
\text { company }\end{array}$ & KPB and NHA & $\mathrm{NHA}$ \\
\hline Construction cost & $\begin{array}{l}\text { NHA arrange } \\
\text { site\&service block } \\
\text { for self-build } \\
\text { housing. Mercy } \\
\text { Center, } \\
\text { Thai-German } \\
\text { foundation } \\
\text { supported credit } \\
\text { fund. Army General } \\
\text { Arthit Kamlang-Ek } \\
\text { built } 140 \text { units of } \\
\text { Bann Gue Ga Rune }\end{array}$ & $\begin{array}{l}\text { CPB } \\
\text { Two-storey shop } \\
\text { houses pay a down } \\
\text { payment of } 200,000 \\
\text { Baht, Three-storey } \\
\text { shop houses pay a } \\
\text { down payment of } \\
600,000 \text { Baht }\end{array}$ & $\begin{array}{l}\text { Self-build housing } \\
\text { with the support by } \\
\text { the Sengki Housing } \\
\text { Cooperative, NHA, } \\
\text { UNDP, the Nederlands } \\
\text { Habitat Committee, } \\
\text { and fund of Bangkok } \\
\text { members of } \\
\text { parliament. }\end{array}$ & $\begin{array}{l}\text { Self-build housing } \\
\text { with the support by } \\
\text { Army General. }\end{array}$ \\
\hline New tenure & $\begin{array}{l}\text { Renewable } 20 \text { years } \\
\text { leasehold }\end{array}$ & 30 years leasehold & Freehold & Freehold \\
\hline $\begin{array}{l}\text { Rental rate/ } \\
\text { repayment }\end{array}$ & & & $\begin{array}{l}\text { Sengki Housing } \\
\text { Cooperative }\end{array}$ & $\begin{array}{l}\text { Army General Arthit } \\
\text { Kamlang-Ek }\end{array}$ \\
\hline
\end{tabular}


$5^{\text {th }}$ International Conference on Civil Engineering, Architecture and Urban Planning Elites

\begin{tabular}{|c|c|c|c|c|}
\hline \multirow[b]{2}{*}{ Issue } & \multicolumn{4}{|c|}{ Facilitator Organizations } \\
\hline & $\begin{array}{c}\text { Moo Baan } \\
\text { Pattana } 70 \text { Rai }\end{array}$ & Thep Pratan & Soi Sengki & $\begin{array}{c}\text { Wat Lad Bua } \\
\text { Kaw }\end{array}$ \\
\hline method & & & $\begin{array}{l}\text { borrowed from } \\
\text { Bangkok Bank to } \\
\text { redeem the land from } \\
\text { KPB. Loan guarantee } \\
\text { with the special fund } \\
\text { by the Nederland } \\
\text { Habitat Committee } \\
\text { through NHA. } \\
\text { Residents repay to } \\
\text { the cooperative. }\end{array}$ & $\begin{array}{l}\text { approached GHB } \\
\text { that provided five } \\
\text { years loan through } \\
\text { NHA. Residents } \\
\text { repay 5,600 } \\
\text { Baht/month to } \\
\text { NHA, ranging from } \\
475 \text { - } 600 \\
\text { Baht/month }\end{array}$ \\
\hline Utility and facility & $\begin{array}{l}\text { NHA and Army } \\
\text { General }\end{array}$ & CPB and NHA & $\mathrm{KPB}, \mathrm{BMA}, \mathrm{NHA}$ & NHA, The Army \\
\hline Basic services & $\begin{array}{l}\text { BMA provides } \\
\text { garbage collection } \\
\text { services }\end{array}$ & CPB and NHA & $\begin{array}{l}\text { BMA provides } \\
\text { garbage collection } \\
\text { services }\end{array}$ & $\begin{array}{l}\text { BMA provides } \\
\text { garbage collection } \\
\text { services }\end{array}$ \\
\hline
\end{tabular}

Data source: Author, 2017

\section{Land Sharing Residents Combined Assets to form Livelihood Strategy}

Social, physical, financial, and human capital are inseparable for original Land Sharing residents in an urban context. The finding confirmed the perspective of Rakodi (2002) and Carney (2003) that there are interrelationships among components of livelihood assets to assist households in assuring their livelihoods.

Diagram 2 draw networks among four livelihood assets possessed by the original Land Sharing households in four case studies. The links illustrate that each asset had relationships with others. For example, even human capital had only five connections, but they were all related to social, physical and financial capital. However, the number of connecting lines did not indicate how strong of the assets to one another but showing livelihood strategy patterns by combining a different portion of assets. 


\section{Diagram 2: Livelihood assets and variables network}

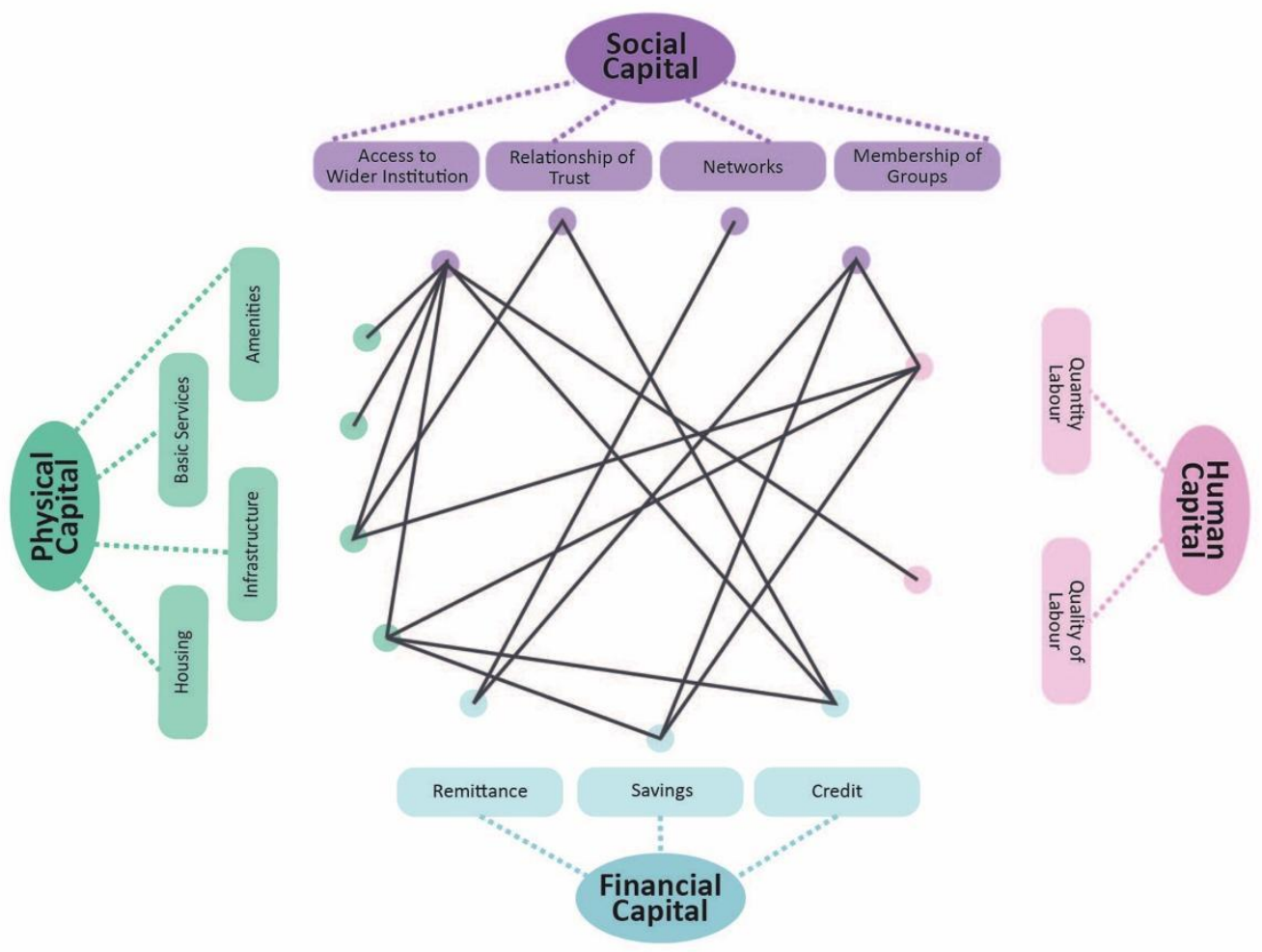

Source: Author, 2017

For example, wealthier households in Thep Pratan traded-off the size of the house to a smaller plot compared to the squatted old house. They were able to stay in the prime area in Bangkok in cheaper rents instead of moving away to get equal housing size in the suburban or much more expensive house in the same size to the previous house. They decided to stay on-site with smaller housing unit with old trustworthy neighbors. The good location gave them better and more job opportunities, which they earned more income and savings for further investment. Also, the same housing area maintains them the work connections they had already established. In sum, the household's livelihood goal was to earn more income, then, they combined physical capital (good location of house), social capital (trustworthy neighbors), financial capital (earnings for more savings) and human capital (work connections and job opportunities in the prime area) together, and it resulted in the decision to remain on the same site in long-term period.

Another example is a household from Moo Baan Pattana 70 Rai. The trade-off is 
the household were stigmatized that they came from slum area. However, living in the project gave an opportunity to run a rental house with low investment because land rent is very cheap, as same as the construction cost was subsidized by NGOs (Mercy Center). Moreover, one of households lived in this area since she was born, so, wide connections in the area gave an opportunity to provide informal loans for others low-income households. Currently, the house of this respondent is the three-story house with two bedrooms, three toilets, and air-conditioned. To conclude, livelihood goal was to have more income and better well-being. So, respondent combined social capital connections and support from PAT and Mercy Center), physical capital (living in Klong Toei area), financial capital (savings to upgrade house) and human capital (running a rental home and informal loans in the area) together. As a result, respondent decided to remain on the same site in a long-term period to enjoy the livelihood outcome.

\section{No Different in Community Size in Choosing Livelihood Strategy}

There were no differences in large or small Land Sharing projects in combining livelihood assets as size of the community did not indicate trust or reciprocity level in the community. Respondents from all case studies had higher trust towards family members and close friends that they have known the person or households for a long period. Also, both large and small communities view renters as outsiders of the community. However, the only saving group that was succeeded was the one in Thep Pratan community. The possible explanation is that the CBP is taking care of the saving group closely. Continuous and close support from the CPB help in maintains the saving group effectively.

For physical capital, all Land Sharing projects' housing was almost equally upgraded and provided infrastructures. Housing size and pattern were decided by residents because it applied self-help housing construction, except for Thep Pratan that all housing provided by the CPB. Materials of the house were resident's choices. Basic services, such as garbage collection were provided by the BMA and residents from all case studies paid the same price.

Wat Lad Bua Kaw is the community that has the highest number of original Land Sharing that still stay on the same site. The reason was not the size of the project, but it is the type of land tenure (freehold) in combination with an average income level of households in the project. For example, Soi Sengki also has freehold tenure but around 
a half of original residents sold their rights to others. Some of them had enough savings to get new housing, and some of them chose to sell their rights to earn lump money.

\section{Conclusions}

The analysis of key findings found that Land Sharing was succeeded to some extent to remain the urban poor in the inner city, not all original residents decided to stay in the project in long-term. Households that decided to stay were influenced by four livelihood assets: social capital, physical capital, financial capital, and human capital. Social and physical capital were dominant factors as they were directly influenced by the decision of the residents. Secured tenure, the location of the house, access to transportation, networks between relatives and friends, as well as groups in the community were an important issue that original Land Sharing concerned. Financial and human capital also played important role in influence the decision of the urban poor. Credits and savings helped the poor in gaining resources to obtain rights on the land and housing and infrastructure construction. Furthermore, available jobs in the nearby area are also important for the urban poor. Training or capacity building program attracted residents if the program directly involved with their existing resources and jobs.

All livelihood assets were inseparable, they help influence the decision of original households to stay on the same site, as it is one of the objectives of Land Sharing. For example, social capital enabled financial and human capital, while physical capital enhanced social capital and gave access to financial and human capital. Without financial capital, original Land Sharing residents were not being able to reach some aspect of physical capital. To illustrate, relationship between savings, networks, and support from outside organizations can be explained as follow: because of credits that residents gained from saving group or community funding in a community, they were able to access to broader funding program or other formal financial markets, such as the city development fund (CDF). Where underlie concepts of community-based finance are networking, collectivity, decentralization (Boonyabancha, 2009) and integrative management using both bottom-up and top-down approaches (Sripanich et al., 2015) in managing the saving group.

There were lessons learned from the Land Sharing concepts implementing in Bangkok that contribute to the current literature on on-site slum upgrading for the urban poor in inner-city. Land Sharing in Bangkok provides a model through which one can use to understand and identify the key component, concepts, and factors that 
enabling the success of the project through which one can use to understand Land Sharing or on-site slum upgrading in other countries. Practitioners, policy maker as well as everyone involved in the implementing of Land Sharing should fully and equally understand the mechanism how livelihood assets influenced the decision of the urban poor to remain on the same site. Besides, the urban poor's behavior and needs should be highly considered to design the strategy and support for the urban poor in designing and managing Land Sharing. Networks among stakeholders and Land Sharing residents should be established to collect knowledge and lessons learned to improve the future projects. A collaboration between landowners, developers, communities, local authority, NGOs, government, and financial institutions should be established.

This research adopted a qualitative research strategy. So, the research result cannot be generalized. Moreover, it is hard to indicate which factor among the livelihood assets is the factor that most influenced the decision of original Land Sharing to remain on-site. Future research around this topic can use quantitative research strategy and test the importance of each asset in shaping the decision of the original Land Sharing to remain on the same site in the long-term period.

\section{WORD COUNT: 4,954}

\section{Abbreviations}

\begin{tabular}{|l|l|}
\hline BMA & The Bangkok Metropolitan Administration \\
\hline BTS & The Bangkok Mass Transit System (Skytrain in Bangkok) \\
\hline CPB & The Crown Property Bureau \\
\hline CDF & Community Development Fund \\
\hline CODI & The Community Organizations Development Institute \\
\hline DPF & The Duang Prateep Foundation \\
\hline KPB & The King's Property Bureau \\
\hline MRT & The Metropolitan Rapid Transit (Subway in Bangkok) \\
\hline NGOs & Non-Governmental Organozations \\
\hline NHA & The National Housing Authority of Thailand \\
\hline PAT & The Port Authority of Thailand \\
\hline
\end{tabular}

\section{References}

Archer, D. (2012). Baan Mankong participatory slum upgrading in Bangkok, Thailand: Community perceptions of outcomes and security of tenure. Habitat 
International, 36(1), 178-184.doi:10.1016/j.habitatint.2011.08.006

Bhatkal, T. \& Lucci, P. (2015). Community-Driven Development in the Slums: Thailand's Experience. London: Overseas Development Institute. Retrieved from https://www.odi.org/sites/odi.org.uk/files/odi-assets/publications-opinion-files /9669.pdf

Blatter, J. \& Blume, T. (2008). In Search of Co-variance, Causal Mechanisms or Congruence? Towards a Plural Understanding of Case Studies. Swiss Political Science Review, 14, 315-356.doi:10.1002/j.1662-6370.2008.tb00105.x

Boonyabancha, S. (2009). Land for housing the poor - by the poor: experiences from the Baan Mankong nationwide slum upgrading programme in Thailand. Environment \& Urbanization, 21(2),309-329.doi:10.1177/0956247809342180

Bourdieu, P. (1985). The social space and the genesis of groups. Theory and Society, 14(6), 723-744. Retrieved May 2, 2017 from http://www.soc.ucsb.edu/ct/pages/JWM/Syllabi/Bourdieu/SocialSpaceGG.pdf

Carloni, A. S. \& Crowley, E. (2005). Rapid Guide for Missions: Analysing local institutions and livelihoods. Rome: FAO.

Carney, D. (2003). Sustainable livelihoods approaches: progress and possibilities for change. Toronto: Finesse Print.

Coleman, J. S. (1988). Social capital in the creation of human capital. American Journal of Sociology, 94(1988), S95-S120.doi:0002-9602/89/9407-0010

DeFilippis, J. (2001). The myth of social capital in community development. Housing Policy Debate, 12(4), 781-806.doi:10.1080/10511482.2001.9521429

Dupont, V. (2008). Slum demolitions in Delhi since the 1990s: An Appraisal. Economic and Political Weekly, 43(28(Jul. 12 - 18, 2008)), 79-87. Retrieved May 5, 2017 from JSTOR database.

Islam, P. P. \& Yap, K. S. (1989). Land-Sharing as a low Income housing policy: An analysis of its potential. Habitat Internationalonal, 13(1), 117-126.doi:10.1016/0197-3975(89)90012-X

Loury, G. C. (1976). A Dynamic Theory of Racial Income Differences. In: Wallace, P. A. \& LeMund, A. (eds.). (1977). Woman, Monorities, and Employment Discrimination. San Diego: Lexington Books, 153-188.

Maglumtong, M. (2016) The Role of Large-Scale-Landlord in Providing Housing for the Urban Poor in Bangkok, Thailand. (Unpublished Master's thesis). The KU Leuven, Leuven, Belgium. 
Meredith, T. \& MacDonald, M. (2017). Community-supported slum-upgrading: Innovations from Kibera, Nairobi, Kenya. Habitat International,60(February 2017), 1-9.doi:10.1016/j.habitatint.2016.12.003

Minnery, J. et. al. (2013). Slum upgrading and urban governance: Case studies in three South East Asian cities. Habitat International, 39, 162-169.doi:10.1016/j.habitatint.2012.12.002

O'Hare, G. (2001). Urban Renaissance: New Horizons for Rio's Favelas. Geography, 86(1 (January 2001)), 61-75. Retrieved May 12, 2017 from JSTOR database.

O'Sullivan, A. (2012). Urban Economics. New York: McGraw.

Porio, E. \& Crisol, C. (2004). Property rights, security of tenure and the urban poor in Metro Manila. Habitat International, 28(2), 203-219.doi:10.1016/S0197-3975(03)00068-7

Putnam, R. D. (1995). Bowling alone: America's declining social capital. Journal of Democracy, 6(1), 65-78.doi:10.1353/jod.1995.0002

Rabé, E. P. (2005). Land Sharing in Phnom Penh: An Innovative but Insufficient Instrument of Secure Tenure of the Poor. Paper presented at Expert Group Meeting on Secure Land Tenure: New Legal Frameworks and Tools, UN-ESCAP, Bangkok, Thailand, 8-9 December 2005, 1-16. Retrieved from https://www.fig.net/resources/proceedings/2005/bangkok_2005_comm7/pape rs/3_3_rabe.pdf

Rabé, P. E. (2010). Land sharing in Phnom Penh and Bangkok : lessons from four decades of innovative slum redevelopment projects in two Southeast Asian "boom towns". Paper presented on April 30th, 2010 at a policy workshop at the Woodrow Wilson Center (Washington, DC), entitled: "Examining „The Places We Live": Slums and Urban Poverty in the Developing World". Washington: Woodrow Wilson Center. Retrieved from https://www.wilsoncenter.org/sites/default/files/Rabe.pdf

Rakodi, C. (2002). A Livelihoods Approach - Conceptual Issues and Definition. In: C. Rakodi and T. Lloyd-Jones eds. (2002). Urban Livelihoods: A People-centered Approach to Reducing Poverty. London: Earthscan, 3-22.

Satterthwaite, D. (2010). Upgrading slums: With and for flum-dwellers. Economic and Political Weekly, 45(10 (March 6-12, 2010)), 12-16. Retrieved May 12, 2017 from JSTOR database.

Sripanich, S., Nitivattananon, V. \& Ranjith, P. (2015). City development fund: A financial mechanism to support housing and livelihood needs of Thailand's urban 
poor. Habitat International, 49, 366-374.doi:10.1016/j.habitatint.2015.05.011

Szreter, S., (2003). The state of social capital: bringing back in power, politics, and history. Theory and Society, 31(5), 573-621. Retrieved May 12, 2017 from JSTOR database.

Talocci, G. \& Boano, C. (12 May 2017). The de-politicisation of housing policies: the case of Borei Keila land-sharing in Phnom Penh, Cambodia. International Journal of Housing Policy, 1-22.doi.org/10.1080/19491247.2017.1298365

Thiel, $S$ van. (2014). Research methods in public administration and public management, an introduction. London/New York: Routledge.

UN-Habitat. (2003). The challenge of clums: Global report on human settlements 2003. Nairobi: United Nations Human Settlements Program.

van Horen, B. (2000). Informal settlement upgrading: Bridging the gap between de facto and de jure. Journal of Planning Education and Research, 19(4), 389-400.doi:10.1177/0739456X0001900408

Vilar, K. \& Cartes, I. (2016). Urban design and social capital in slums. Case study: Moravia's neighbourhood, Medellin, 2004 - 2014. Procedia - Social and Behavioral Science, 216(6 January 2016), 56-67.doi: 10.1016/j.sbspro.2015.12.008

Wekesa, B. W., Steyn, G. S. \& Oteino, F. A. O. (Fred). (2011). A review of physical and socio-economic characteristics and intervention approaches of informal settlements. Habitat International, 35, 238-245.doi:10.1016/j.habitatint.10.09.006 